\title{
Nexus Between Foreign Direct Investment and Economic Growth in Nigeria: The Role of Exchange Rate
}

\author{
Nya'akunat Elisha-Hosea Batat, Ezekiel Ahmadu \\ Department of Economics, Kaduna State University, Kaduna, Nigeria
}

Email address:

batat247@gmail.com (N. Elisha-Hosea B.), ezekielahmadu@gmail.com (E. Ahmadu)

\section{To cite this article:}

Nya'akunat Elisha-Hosea Batat, Ezekiel Ahmadu. Nexus Between Foreign Direct Investment and Economic Growth in Nigeria: The Role of Exchange Rate. Journal of Investment and Management. Vol. 10, No. 1, 2021, pp. 13-21. doi: 10.11648/j.jim.20211001.13

Received: January 14, 2021; Accepted: February 6, 2021; Published: April 23, 2021

\begin{abstract}
Having reviewed previous empirical studies on the relationship between foreign direct investment and economic growth, limited attention was given on the role of exchange rate on the relationship between foreign direct investment and economic growth. Therefore this study investigates the role of exchange rate on the relationship between foreign direct investment and economic growth over the period 1986 to 2018 using annual time series data sourced from the Central Bank of Nigeria Statistical Bulletin. Augmented Dicker-fuller Unit Root Test and ARDL model were used for the analyses. The ARDL Bounds test to cointegration revealed that economic growth, foreign direct investment, export, import and exchange rate do not have long run relationship over the period under study. The results showed that foreign direct investment has positive relationship with economic growth at maximum, average and minimum level of exchange rate but the relationship is only significant at maximum level over the period under study. This means that at maximum level of exchange rate, an increase in foreign direct investment will lead to a risein economic growth. The results also showed that export has significant positive relationship with economic growth meaning that an increase in export will lead to a rise in economic growth while import showed insignificant negative relationship with economic growth. Based on the results, the study recommended that further depreciation of Nigeria's currency should be encourage so as to allow more inflow of foreign direct investment considering its positive impact on economic growth while the Nigerian Government is encouraged to design and implement policies that will spur export by eliminating stringent excise duties and discouraging import which exerts negative influence on economic growth.
\end{abstract}

Keywords: Economic Growth, Exchange Rate, Foreign Direct Investment

\section{Introduction}

Over the past two decades there has been a rising attention by researchers on the effectiveness of foreign direct investment on economic growth of developing nations. As a result, third world economists and policy makers have undertaken fiscal and financial reforms to encourage the inflow of foreign direct investment (FDI) with the expectation that it will bring new technology, know-how, managerial skills, create employment and generate revenue that has the tendency to assist the host country to break out of the vicious cycle of underdevelopment.

According to the Organization for Economic Corporation and Development (OECD) [27] global foreign direct investment flows decreased by 18 percent in 2017 compared to 2016, to USD 1411 billion. This represents 1.8 percent of global gross domestic product (GDP), compared to 2.3 percent in 2016 and 2.5 percent in 2015 , but is comparable to levels recorded between 2012 and 2014. In the last quarter of 2017 , foreign direct investment flows reached its lowest level since 2013 (USD 280 billion). In 2017, the United States was the major recipient of foreign direct investment globally (USD 287 billion) followed by China (USD 168 billion), Brazil (USD 63 billion), the Netherlands (USD 58 billion excluding resident SPEs), France (USD 50 billion), Australia (USD 49 billion), Switzerland (USD 41 billion) and India (USD 40 billion).

According to the National Bureau of Statistics [22] the flow of foreign direct investment into Nigeria has been decreasing from $2,277.04$ in 2014 to $1,446.62$ in 2015 , and from 1,044.02 in 2016 to 981.75 in 2017 (all in \$ million). The United Kingdom maintained its lead in capital 
investment in Nigeria in the first quarter of 2018, with $\$ 2.25$ billion capital investment (with FDI inclusive). This inflow accounted for 35.73 percent of the entire capital inflow in first quarter of 2018.

The rising importance of foreign direct investment as an important source of external funding for receiving countries has led to compelling realization which dictates that foreign direct investment should be harnessed to promote domestic investment believing it augments domestic investment, which is crucial in attaining sustained growth and development.

However, exchange rate exerts considerable effect on the amount of foreign direct investment flow and the allocation of investment in a country (Goldberg, [17]) Existing literature on exchange rate and foreign direct investment inflow produced mixedresults; while some studies revealed positive influence of exchange rate on foreign direct investment others revealed negative influence of exchange rate on foreign direct investment (Lily, Kogid, Mulok, Sang, \& Asid, [20]).

Nigeria has offered generous incentives to attract foreign direct investment inflows and, in addition, undertaken diverse macroeconomic reforms. Since the returned to democracy in 1999 various economic policies and programs have been initiated in order to change Nigeria's social, economic and political philosophy that will returned the country on the path of economic prosperity. The Obasanjo's administration introduced a blue print tagged 'National Economic Empowerment and Development Strategy (NEEDS)' it is a medium term planning strategy containing all policies and programmes of the federal government for the period 2003-2007 and beyond. NEEDS differs from other macro-economic plan document because it comprehensively comprise of vision, goals and principles of a new Nigeria that was centered on four main policies of wealth creation, employment generation, poverty eradication and value reorientation (Ikeanyibe, [18]). According to National Planning Commission [23], NEEDS aimed at creating a Nigeria that Nigerians can proudly belong to and grateful to inhabit, a Nigeria that promotes self dependence, entrepreneurship, innovation, rewards hard work, protects lives and property, and offers its children better prospects and opportunities they may be tempted to seek in other developed countries of the world.

Alhaji Umaru Musa Yar'Adua (Late) who succeeded president Obasanjo initiated a policy reform called "Seven (7) point agenda" aimed at improving the quality of infrastructural facilities and ensuring the security of lives and property while in 2011, President Goodluck Ebele Jonathan initiated a complementary policy tagged the transformation agenda. The agenda focused on non-inflationary growth, employment generation, poverty alleviation and value reorientation of the citizenry. Arms and Institutions of government such as the national assembly, judiciary, electoral umpire and armed forces were challenged to work tirelessly to re-invent the wheel to property and human right protection and conducive business environment in order to achieve the desired inherent benefits of the agenda in promotingeconomic growth and development of the country.

In recent time, federal government of Nigeria has grown much concern over the threat and challenges facing the country especially, growing insecurity; insurgency in the north east, farmers-herders clashes in the middle belt, kidnapping and alarming rate of corruption. To this end, the president Muhammadu Buhari led government has reviewed the country's entire security architecture and the security agencies reposition and empowered in order to curb those security challenges. The Muhammadu Buhari led government launched the Economic Recovery Growth Plan (ERGP) in April 2017. It is a medium term all-round developmental plan that is focused on restoring growth, investing in people and building an economy that can compete globally. (National Planning Commission, [24]). One year later, there was sustained recovery from recession and growth in GDP to 1.92 percent as at the last quarter of 2017. This growth accelerated from a 1.4 percent growth in the prior period. It was the third consecutive quarter of expansion and the strongest since the last quarter of 2015. Inflation was been moderate with a falling trend for 14 consecutive months to 13.34 percent as at first quarter of 2018 when compared to 18.33 percent in October 2016.

Rising crude oil prices and sustained dialogue with Niger Delta militants brought stability in oil producing stateswhich raised output and foreign reserves to $\$ 46 \mathrm{~B}$ in first quarter of 2018, the highest in 5 years. There has been an increase in non-oil revenue generated from agricultural sector. The contribution of Agricultural sector to nominal GDP stood at 21.97 percent. This figure is higher than the rates recorded in the last quarter of 2016 and lower than the third quarter of 2017 at 21.35 percent and 24.44 percent respectively. Annual growth rate stood at 11.29 percent in 2017 as against 9.61 percent in 2016. The naira has gradually settled to $\$ 360$ $\# 365$ in the parallel market as at April 2018.

Adeolu [3] categorized the polices embarked upon by the Nigerian government to attract foreign investors as a result of the introduction of the Structural Adjustment Program in 1986 into five: the establishment of the Industrial Development Coordinating Committee (IDCC), investment incentive strategy, non-oil export stimulation and expansion, the privatization and commercialization programme, and the shift in macroeconomic management in favour of industrialization, deregulation and market-based arrangements.

The overall aim of these aforementioned policies is the realization of economic growth and development in which foreign direct investment is considered an important driver due to the low level of savings in the country. Therefore it is expedient to assess the impact of foreign direct investment on Nigeria's economic growth while analyzing the role of exchange rate in such relationship within the period in which major economic reforms were taken to spur economic growth (1986 - 2018) in Nigeria. In order to achieve this objective, the paper is divided into sections: section two reviewed literature while section three and four presented the methodology and data analysis respectively; lastly section five gave the conclusion and policy recommendations. 


\section{Literature Review}

\subsection{Conceptual Literature}

Capital flow can be divided into three main investment types: Foreign direct investment (FDI), Portfolio Investment and other Investments, each comprising various subcategories. Foreign direct investment is a major component of foreign investment. It is believed that foreign direct investment has positive impact on economic growth of a country through numerous means. It augments domestic investment, which is integral to the attainment of sustained growth and development.

Lily et al [20] defined foreign direct investment as an international flow of capital that provides a parent company or multinational enterprise (MNEs) with control over foreign affiliates. Foreign direct investment referred to as an investment made to acquire a lasting interest in an enterprise operating in an economy other than that of the investor, the investor's purpose being to have an effective voice in the management or control of an enterprise (IMF, 1977; 1993 as cited by Cockcraft and Ridell [12]. As a guideline, FDI should account for at least 10 percent of the voting stock. In Nigeria, FDI is defined as investment undertaken by an enterprise that is either wholly or partly foreign-owned. Decree no. 16 of 1995 that created the Nigerian Investment Promotion Commission (NIPC) and the Foreign Exchange Decree of 1995, all out rightly encourages FDI in Nigeria.

Adigwe, Ezeagba, and Francis [4], described foreign direct investment in different ways. Firstly it may involve parent enterprise injecting equity capital by purchasing shares in foreign affiliates. Secondly, it may take the form of reinvesting the affiliate's earning. Lastlyit may include foreign investment as a share of Gross Domestic Product which has become the largest source of capital movement from developed nations to developing nations. Goldberg [17] defined exchange rate as the domestic currency price of a foreign currency. It is the rate at which one currency will be exchanged for another.

\subsection{Theoretical Literature and Frame Work}

\section{The Big Push Theory}

Big push theory is among the early theories in the field of development economics; it was developed in the year 1943 by Paul Rosenstein-Rodan while further contributions were later made by Murphy, Schleifer, and Vishny on the theory. The theory exposed how developing countries can achieve rapid industrialization via diverse large investments and coordination (Murphy, Schleifer, \&Vishny, [21]). Developing countries generally suffer from inadequate capital needed to provide this big push in investments. Consequently, the big push hypothesis is often advocated to justify the inflow of foreign funds that will spur investments in developing economies. According to Easterly, [13] a lot of economists advocated a big push involving a combination of a large rise in aid flow, and a corresponding large scale investment in numerous sectors to launch the economy on the path of prosperity, leading to growth and down play in poverty rate.

Jhingan, [19] noted that the big push theory entails that a bit by bit movement may not successfully drive the economy on the path of progress or development required by developing countries for them to escape from their state of economic backwardness, but a necessary condition must be met which is deploying a minimum amount of resources for investment. It becomes necessary to secure external economies brought about as a result of simultaneous establishment of technical interdependent industries; hence large amount of external investment is needed as a precondition for launching the economy on the path of growth accordingly.

\subsection{Empirical Review}

Alege and Ogundipe, [5] examined the relationship between foreign direct investment and economic growth on Economic Community of West African States from 19702011, they adopted the System-GMM panel estimation procedure. The results revealed an insignificant negative relationship of foreign direct investment on economic growth. The authors attributed the result to the nature of the foreign direct investment flow which is resource-seeking.

Ansarul, Ashok and Syeda [8] examined the role of foreign direct investment on Kuwait's economic rise for the period 2000-2014. They employed correlation analysis of variance (ANOVA) and regression statistical tools in their analysis using secondary data from IMF Report, and other sources. The results reveal that the relationship between foreign direct investment and economic growth is positive while Edward [14] found an insignificant negative relationship between foreign direct investment and Rwanda's economic growth in his study that evaluated the effect of foreign direct investment on Rwanda's economic growth from 1970-2011. He tested two hypotheses which related economic growth and foreign direct investment using multiple regression and World Bank data.

Bakare, Tunde, and Bashorun, [9] studied the Two Gap model; bridging the gap with foreign direct investment in the Nigerian economy. They sought the effect of the two gaps on Nigeria's economic performance and if foreign direct investment is capable of filling it. They adopted error correction mechanism which revealed that the two gaps slows economic growth, and that although foreign direct investment is a bridge, it is not sufficient in the short run neither is it reliable in the long run because it encourage imports in both periods, which could aggravate foreign exchange gap. Adegboye, Ogbebor and Egharyba [1] noted that for a developing country as Nigeria, a positive flow of external capital is of paramount importance. In their study, dynamics effects of external capital inflow in the Nigerian economy was examined using the Vector Error Correction Mechanism (VECM) technique from 1981-2012. Results from their analysis showed that classifying foreign capital flows into direct and portfolio have significant positive relevance in terms of their effects on growth in Nigeria as revealed by their coefficients. 
Alexander, Joshua and Tauhid [6] investigated the relationship between foreign direct investment and Nigeria's economic growth using Johansen unrestricted cointegrationtechnique in their work which revealed a long run significant relationship between foreign direct investment and economic growth and that foreign direct investment increases economic growth in Nigeria indicating a positive measure of growth. Oyali and Okafor [25] conducted a detailed examination of foreign direct investment and economic growth nexus in Nigeria using secondary data and OLS and equations techniques. Their result reveals that a rising foreign direct investment will speedily help in achieving vision 2020 because foreign direct investment is positively related to economic growth.

Adeleke, Olowe and Fasesin [2] and Benedict and John [10] all adopted the Ordinary Least Square regression technique (OLS) to analyze the influence of foreign direct investment on Nigeria's economic growth using secondary data. Their results revealed a positive relationship between foreign direct investment and economic growth. Adigwe et al [4] analyzed the relationship between foreign direct investment and economic growth using secondary data collected from the Statistical Bulletin of the CBN from 20082013. They tested their study hypothesis using Pearson Correlation. The results revealed a significant relationship between foreign direct investment and economic growth meaning there exists a direct relationship between economic growth and foreign direct investment in Nigeria.

Johansen cointegration and vector error correction were adopted by Egwaikhide [15] to assess the effect of disaggregated foreign direct investment on real growth of Nigeria from 1980-2009. It was found that only the telecom sector had robust effect on real growth and having the potential to grow over time in the long run while the petroleum, mining, agriculture and manufacturing sectors have weak effect on real growth. Fredrick and Manasseh [16] in their study on the influence of foreign direct investment on economic growth utilized quarterly data from 1980-2009 with bias on the influence of foreign direct investment flow into agriculture, manufacturing and telecommunication sectors. The results reveal that foreign direct investment into telecommunication and manufacturing sectors have positive effect on economic growth while foreign direct investment into agricultural sector has negative effect on economic growth.

Having reviewed previous empirical studies on the relationship between foreign direct investment and economic growth, limited attention was given on the role of exchange rate on the relationship between foreign direct investment and economic growth. Therefore this study will add to knowledge by investigating the role of exchange rate on the relationship between foreign direct investment and economic growth in Nigeria

\section{Materials and Methods}

\subsection{Nature and Source of Data}

This paper used annual time series data from 1986 to 2018 . The data were obtained from Central Bank of Nigeria (CBN), 2018 Statistical Bulletin

\subsection{Model Specification}

In order to assess the relationship between foreign direct investment and economic growth, a multivariate model is adopted from the work of Aminu and Batat [7] who interrogated whether foreign aid accelerated economic growth in Nigeria.

$$
G D P=f(O D A, G C F, E X P T, I M P)
$$

Where:

$\mathrm{GDP}=$ Gross Domestic Product (Proxy for Economic Growth)

ODA $=$ Official Development Assistance

$\mathrm{GCF}=$ Gross Capital Formation (Proxy for Domestic Investment)

$\mathrm{EXP}=$ Exports

$\mathrm{IMP}=$ Imports

For the purpose of this study, the above model in equation (1) was adopted and then replacesOfficial Development Assistance (ODA) and Gross Capital Formation (GCF) with Foreign Direct Investment (FDI) and Exchange Rate (EXCR) respectively which gave rise to a new model as follows:

$$
G D P=f(F D I, E X P T, I M P, E X C R)
$$

The behavioural equation is:

$$
\log (G D P) t=a_{0}+b_{1} \log (F D I) t+b_{2} \log (E X P T) t+b_{3} \log (I M P) t+b_{4} \log (E X C R) t+U_{t}
$$

Where:

$\log =$ Natural logarithm, $\mathrm{a}_{0}=$ Intercept, $\mathrm{b}_{1}-\mathrm{b}_{4}=$ Coefficients of the independent variables

$\mathrm{GDP}=$ Gross Domestic Product (Proxy for Economic Growth), FDI $=$ Foreign Direct Investment, EXPT $=$ Exports, $\mathrm{IMP}=$ Imports, EXCR=Exchange Rate, $\mathrm{U}_{\mathrm{t}}=$ Error term, $\mathrm{t}=$
Time period.

In addition, the study introduced an interaction term into the above model in equation (3) so as to capture the role of exchange rate on foreign direct investment and economic growth nexus as follows:

$$
\log (\text { GDP })=\varnothing_{0}+\varnothing_{1} \log (\text { FDI })_{\mathrm{t}}+\varnothing_{2} \log (\text { EXPT })_{\mathrm{t}}+\varnothing_{3} \log (\mathrm{IMP})_{\mathrm{t}}+\varnothing_{4} \log (\mathrm{EXCR})_{\mathrm{t}}+\varnothing_{5}(\mathrm{FDI} * \mathrm{EXCR})_{\mathrm{t}}+\mathrm{e}_{\mathrm{t}}
$$

Where:

$\log =$ Natural logarithm, $\varnothing_{0}=$ Intercept, $\varnothing_{1^{-}} \varnothing_{5}=$
Coefficients of the independent variables $\mathrm{GDP}=$ Gross Domestic Product (Proxy for Economic 
Growth), FDI $=$ Foreign Direct Investment, EXPT $=$ Exports, $\mathrm{IMP}=$ Imports, $\mathrm{EXCR}=$ Exchange Rate, FDI*EXCR= Interaction Term, $\mathrm{U}_{\mathrm{t}}=$ Error term, $\mathrm{t}=$ Time period.

Furthermore, the interpretation of interaction term should not be base on a single constant effect but it should be based on multiple marginal effects depending on the variables upon which the interaction is based (Brambor, Clark \&Golder,
[11]). And the significant of the marginal effect can only be concluded by using new standard errors (Brambor et. al, [11]). Therefore, the marginal effect of foreign direct investment on economic growth when foreign direct investment is interacted with exchange rate is shown below in equation (5) while the new standard error of the marginal effect is shown in equation (6)

$$
\frac{\partial \log (G D P)}{\partial \log (F D I)}=\emptyset_{1}+\emptyset_{5} E X C R
$$

Standard Error of

$$
\frac{\partial \log (G D P)}{\partial \log (\mathrm{FDI})}=\sqrt{\operatorname{Var}\left(\emptyset_{1}\right)+E X C^{2} \operatorname{Var}\left(\emptyset_{5}\right)+2 \cdot E X C R . \operatorname{Cova}\left(\emptyset_{1}, \emptyset_{5}\right)}
$$

\subsection{Variables Description and Expected Signs}

GDP (Real GDP) is growth rate of output; FDI is the ratio of foreign direct investment to GDP, while EXPT and IMP are ratios of export and imports to GDP respectively. Exchange rate is the rate at which Nigeria currency is exchange to United State dollars. Interaction term (FDI*EXCR) is the product of foreign direct investment and exchange rate. The apriori expectations regarding the signs of parameters are: $\emptyset_{1}, \varnothing_{2}, \varnothing_{4}, \varnothing_{5}>0, \varnothing_{3}<0$.

\subsection{Estimation Technique}

\subsubsection{Unit Root Test}

The study conducted unit root test to check the stationarity state of the variables using Augmented Dickey-Fuller Unit Root Test method

\subsubsection{Bounds Test to Cointegration}

The study carried out cointegration test to check whether the variables have a long run relationship using ARDL Bounds Test to cointegration method.

\subsubsection{Autoregressive Distributed Lags (ARDL) Model}

The study used Autoregressive Distributed Lags (ARDL) model estimation technique to analyse the data based on the fact that the variables are I(1) and I(0)

\section{Results and Discussion}

\subsection{Descriptive Statistic of the Variables}

Table 1 below showed the descriptive statistic of the variables used by the study. The statistics were presented in terms oftheir maximum value, mean value, minimum value and standard deviation. The maximum value of Exchange Rate (EXCR) over the period under study is $\$ 300.121$ which was recorded in 2017, while the minimum value is $\$ 2.0206$ which was recorded in 1986. On average, the value of EXCR is 100.4739. Similarly, the maximum value of Gross Domestic Product (GDP) is $\$ 69,810.02$ billion which was recorded in 2018 while the minimum value is $\$ 15,237.99$ billion which was recorded in 1986. The value of GDP on average over the period under study is $\$ 36,628.29$ billion. For Foreign Direct Investment (FDI), the maximum value is 907673 which was recorded in 2018 while the minimum value is 9313.6 which was recorded in 1986 . On average, the value of FDI over the period under study is 308080.1

\begin{tabular}{|c|c|c|c|c|c|c|}
\hline & GDP & FDI & EXPT & IMP & $\overline{\text { EXCR }}$ & FDI*EXCR \\
\hline Mean & 36628.29 & 308080.1 & 5548.963 & 3850.784 & 100.4739 & 53045596 \\
\hline Median & 28957.71 & 166632 & 1945.7 & 1512.7 & 118.5669 & 20013370 \\
\hline Maximum & 69810.02 & 907673 & 19280.04 & 13445.11 & 300.121 & $2.72 \mathrm{E}+08$ \\
\hline Minimum & 15237.99 & 9313.6 & 8.9 & 6 & 2.0206 & 18819.06 \\
\hline Std. Dev. & 19418.55 & 301149 & 5912.531 & 4382.113 & 83.31678 & 75513603 \\
\hline Skewness & 0.566005 & 0.913733 & 0.730262 & 0.834999 & 0.592303 & 1.757081 \\
\hline Kurtosis & 1.758866 & 2.52946 & 2.18842 & 2.110891 & 2.832685 & 5.20361 \\
\hline Probability & 0.1437 & 0.086448 & 0.146701 & 0.085363 & 0.37381 & 0.000007 \\
\hline Sum & 1208733 & 10166642 & 183115.8 & 127075.9 & 3315.638 & $1.75 \mathrm{E}+09$ \\
\hline Sum Sq. Dev. & $1.21 \mathrm{E}+10$ & $2.90 \mathrm{E}+12$ & $1.12 \mathrm{E}+09$ & $6.14 \mathrm{E}+08$ & 222133.9 & $1.82 \mathrm{E}+17$ \\
\hline Observations & 33 & 33 & 33 & 33 & 33 & 33 \\
\hline
\end{tabular}

Table 1. Descriptive statistic of the variables.

Source: Author's Computation, 2020 using Eview 9. GDP= Gross Domestic Product, FDI=Foreign Direct Investment, EXPT=Export, IMP=Import, $\mathrm{EXCR}=$ Exchange Rate, FDI*EXCR=Interaction Term,

In the same vein, the maximum values of Export (EXPT) and Import (IMP) over the period under study are; $\$ 19,280.04$ billion in 2018 and $\$ 13,445.11$ billion in 2018 respectively. While the minimum values of EXPT and IMP are; $\$ 8.9$ billion in 1986 and $\$ 6$ billion in 1986 respectively. On average, the values of EXCR and IMP are; $\$ 5548.963$ and $\$ 3850.784$ respectively 


\subsection{Unit Root Test}

The results of the unit root test presented in Table 2 below showed that $\log ($ GDP $), \quad \log$ (FDI), EXCR and $\log ($ RGDP*INFR $)$ are not stationary at level but they became stationary after taking the first difference using 5 percent significant level. However, $\log ($ EXPT) and $\log ($ IMP) are stationary at level using 5 percent significant level. Therefore, the variables under this study are integrated of order one and order zero that is $\mathrm{I}(1)$ and $\mathrm{I}(0)$

Table 2. Summary of Unit Roots Test (Augmented Dickey-Fuller Test).

\begin{tabular}{|c|c|c|c|c|c|c|c|}
\hline Variables & $\begin{array}{l}\text { Test statistics } \\
\text { at level }\end{array}$ & $\begin{array}{l}5 \% \text { critical } \\
\text { value at level }\end{array}$ & $\begin{array}{l}\text { P-valueat } \\
\text { level }\end{array}$ & $\begin{array}{l}\text { Test statistics at } \\
\text { first difference }\end{array}$ & $\begin{array}{l}5 \% \text { critical value at } \\
\text { first difference }\end{array}$ & $\begin{array}{l}\text { p-valueat } \\
\text { firstdifference }\end{array}$ & $\begin{array}{l}\text { Order of } \\
\text { integration }\end{array}$ \\
\hline $\log ($ GDP $)$ & -0.704086 & -2.960411 & 0.8313 & -3.113341 & -2.960411 & 0.0359 & $\mathrm{I}(1)$ \\
\hline $\log (\mathrm{FDI})$ & -1.737869 & -2.963972 & 0.4028 & -4.443053 & -2.960411 & 0.0014 & $\mathrm{I}(1)$ \\
\hline $\operatorname{Iog}(\mathrm{EXPT})$ & -2.959180 & -2.957110 & 0.0498 & - & - & - & $\mathrm{I}(0)$ \\
\hline $\log (\mathrm{IMP})$ & -3.473932 & -2.960411 & 0.0157 & - & - & - & $\mathrm{I}(0)$ \\
\hline EXCR & -2.563930 & -2.957110 & 0.1108 & -5.709049 & -2.960411 & 0.0000 & $\mathrm{I}(1)$ \\
\hline LogFDI*EXCR & -2.638413 & -2.957110 & 0.0960 & -4.922950 & -2.960411 & 0.0004 & $\mathrm{I}(1)$ \\
\hline
\end{tabular}

Source: Author's Computation, 2020 using Eview 9. GDP= Gross Domestic Product, FDI=Foreign Direct Investment, EXPT=Export, IMP=Import, EXCR $=$ Exchange Rate, FDI*EXCR $=$ Interaction Term, Log= Natural Logarithms

Table 3. ARDL Bounds Test.

\begin{tabular}{llll}
\hline \multirow{2}{*}{ Computed F- statistic } & \multirow{2}{*}{ K } & 5\% critical Bound Test value & \\
\cline { 3 - 4 } & 5 & Lower Bound & Upper Bound \\
\hline 2.041677 & 5 & 2.62 & 3.79 \\
\hline
\end{tabular}

Source: Author's Computation, 2020 using Eview 9

\subsection{Bounds Test to Co-integration}

Considering that the variables used for this study are integrated of order one and zero as revealed by the unit root test in Table 2 above. The study resolved to employ the Bounds Test to Cointegration to check whether the variables have long run relationship as shown in Table 3 above. The Fstatistic value of 2.041677 from the ARDL bound testing presented in Table 3 above is smaller than the lower bound value of 2.62 at 5 percent level. Therefore, on this basis the null hypothesis of no long run relationship is accepted and conclude that Gross Domestic Product (Proxy for Economic Growth), Foreign Direct Investment, Exports, Imports, Exchange Rate and the Interaction term do not have long run relationship over the period under study

\subsection{Autoregressive Distributed Lags (ARDL) Short-Run Estimate}

To study employed Autoregressive Distribution lag (ARDL) model as formulated by Pesaran and Shin [26] for the analysis of the data based on the fact that the variables used for this paper are of mixed order of integration as shown by the unit root test in Table 2 above. This method was employed because it is applicable irrespective of whether the repressors in the model are purely $\mathrm{I}(0)$ or $\mathrm{I}(1)$ or mixed. Furthermore, to estimate the variables in the model, the study selected ARDL $(1,0,0,0,0,1)$ and the result is presented in Table 4 below.

Table 4. ARDL Short-Run Estimate.

\begin{tabular}{lllc}
\hline Dependent Variable: LOG(GDP) & \multicolumn{2}{l}{ Selected Model: ARDL(1, 0, 0, 0, 0, 1) } & \\
\hline Variable & Coefficient & Std. Error & t-Statistic \\
\hline LOG(GDP(-1)) & 1.005041 & 0.041093 & 24.45791 \\
LOG(FDI) & 0.074481 & 0.028969 & 2.571092 \\
LOG(EXPT) & 0.028614 & 0.012689 & 2.254877 \\
LOG(IMP) & -0.026911 & 0.028389 & -0.947909 \\
EXCR & 0.000300 & 0.000238 & 1.261757 \\
LOG(FDI*EXCR) & 0.007424 & 0.002227 & 3.333019 \\
LOG(FDI*EXCR(-1)) & 0.038612 & 0.016756 & 2.304419 \\
C & 0.166525 & 0.420199 & 0.000 \\
R-squared & 0.727475 & & 0.3529 \\
Adjusted R-squared & 0.706738 & & 0.2192 \\
Durbin-Watson stat & 1.887798 & & 0.0280 \\
\hline
\end{tabular}

Source: Author's Computation, 2020 using Eview 9. GDP= Gross Domestic Product, FDI=Foreign Direct Investment, EXPT=Export, IMP=Import, $\mathrm{EXCR}=$ Exchange Rate, FDI*EXCR=Interaction Term, Log= Natural Logarithms

The ARDL short run estimated presented in Table 4 above has a good fit with an Adjusted R-square value of 70 percent. It showed that about 70 percent of economic growth proxy by GDP is being explained by Foreign Direct Investment,
Export, Import, Exchange Rate and Interaction Term over the period under study while the remaining 30 percent is being explained by other variables not captured by the model. The result further revealed that the explanatory variables are 
jointly significant to explain economic growth being the dependent variables as revealed by the significant probability value of the F statistic which is less than 5 percent

The interaction term (FDI*EXCR) shows significant positive relationship with economic growth using 5 percent level. To be specific, a unit increase in interaction term will bring about 0.007 percent increase in economic growth over the period under study which is in line with the apriori expectation of the study. This means that exchange rate positively affect foreign direct investment which pushes and stimulate economic growth in the right direction.

The results also revealed that Foreign Direct Investment (FDI) has significant positive relationship with economic growth which is in line with apriori expectation of the study and also similar to the work of Alexander, Joshua and Tauhid [6] and Adeleke, Olowe and Fasesin [2] on the relationship between foreign direct investment and Nigeria's economic growth. Specifically, a unit increase in FDI will bring about 0.074481 percent significant increase in economic growth using 5 percent level. Similarly, the results also showed that Export (EXPT) has significant positive relationship with economic growth and it is also in line with the apriori expectation of the study. Precisely, a unit increase in EXPT will bring about 0.028614 percent increase in economic growth over the period under study.

Furthermore, the results also revealed that Import (IMP) has insignificant negative relationship with economic growth which is in line with the apriori expectation of the study. Precisely, a unit increase in IMP will bring about 0.026911 percent decrease in economic growth. Similarly, Exchange Rate (EXCR) has insignificant positive relationship with economic growth which is in line with the apriori expectation of the study. Specifically, a unit increases in EXCR will bring about 0.000300 increase in economic growth over the period under study.

\subsection{Marginal Effect of Foreign Direct Investment on Economic Growth for Maximum, Average and Minimum Level of Exchange Rate}

The marginal effect of foreign direct investment on economic growth for maximum, average and minimum level of exchange rate is presented in Table 5 below. From the table below, the marginal effect of foreign direct investment on economic growth is positive for maximum, average and minimum level of exchange rate and it is significant only at maximum level of exchange rate using 5 percent level. This means that at maximum level of exchange rate, foreign direct investment has significant positive relationship with economic growth. However, at average and minimum level of exchange rate foreign direct investment shows insignificant positive relationship with economic growth over the period under study. To be precise, a change in foreign direct investment at maximum, average and minimum level of exchange rate will bring about 2.3026 percent, 0.82039 percent and 0.0894 percent increase in economic growth respectively over the period under study.

Table 5. Marginal Effect of Foreign Direct Investment on Economic Growth for Maximum, Average and Minimum Level of Exchange Rate.

\begin{tabular}{lll}
\hline At maximum level of exchange rate (300.121) & At verage level of exchange rate (100.4739) & At minimum level of exchange rate rate (2.0206) \\
\hline$\frac{\partial \log (G D P)}{\partial \log F D I}=\emptyset_{1}+\emptyset_{5} E X C R$ & $\frac{\partial \log (G D P)}{\partial \log F D I}=\emptyset_{1}+\emptyset_{5} E X C R$ & $\frac{\partial \log (G D P)}{\partial \log F D I}=\emptyset_{1}+\emptyset_{5} E X C R$ \\
$=0.074481+0.007424(300.121)$ & $=0.074481+0.007424(100.4739)$ & $=0.074481+0.007424(2.0206)$ \\
Marginal Effect $=2.3026$ & Marginal Effect $=0.8203$ & Marginal Effect=0.0894 \\
New Std. Error $(0.956)$ & New Std. Error $(0.929)$ & New Std. Error $(0.916)$ \\
t. stat $[2.408]$ & t. stat $[0.882]$ & t. stat [0.097] \\
\hline
\end{tabular}

Source: Author's Computation, 2020. Note: t-sta $>1.96$ (significant at 5\%), t-sta $<1.96$ (insignificant at 5\%).

Table 6. Calculation of new standard error.

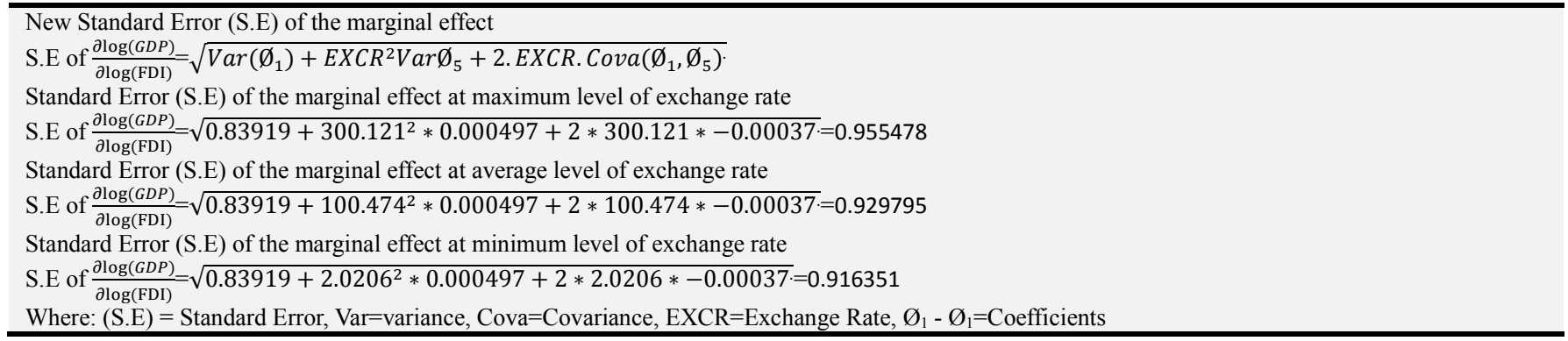

Source: Author's Computation, 2020. The calculation of the new standard error was carried out as suggested by Brambor, etal [11].

\subsection{Diagnostic Checking}

\subsubsection{Residual Normality Test}

The probability value of the Jarque-Bera statistic of figure 1 below is 0.983064 which is more than 5 percent. This indicates that residual of the model is normally distributed.

\subsubsection{Autocorrelation and Heteroscedasticity Test}

The short-model is free from autocorrelation and heteroscedasticity as suggested by the Breusch-Godfrey Serial Correlation 
LM Test with an observed R-square p-value of 0.5938 and Breusch-Pagan-Godfrey heteroscedasticity test with an observed R square p-value of 0.06 which are all more than 5 percent as shown in Table 7 below.

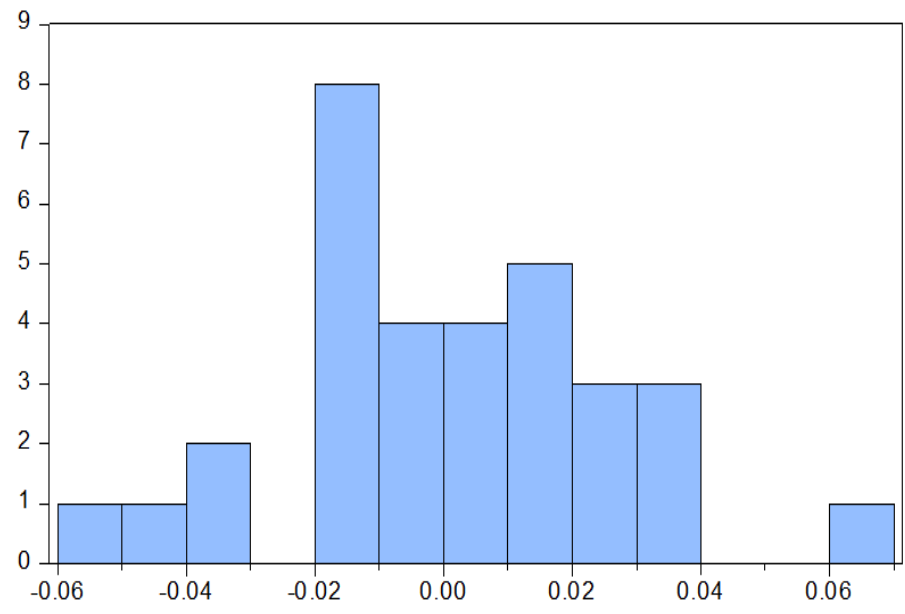

\begin{tabular}{|ll|}
\hline \multicolumn{2}{|l|}{ Series: Residuals } \\
Sample 1987 2018 \\
Observations 32 \\
Mean & $-2.54 \mathrm{e}-16$ \\
Median & -0.002136 \\
Maximum & 0.063469 \\
Minimum & -0.058812 \\
Std. Dev. & 0.026140 \\
Skewness & 0.079074 \\
Kurtosis & 3.024719 \\
& \\
Jarque-Bera & 0.034163 \\
Probability & 0.983064 \\
\hline
\end{tabular}

Figure 1. Residual Normality Test.

Table 7. Test for Autocorrelation and Heteroscedasticity.

\begin{tabular}{lrll}
\hline Breusch-Godfrey Serial Correlation LM Test & & \\
F-statistic & 0.370461 & Prob. F(1,28) & 0.6946 \\
Obs*R-squared & 1.042591 & Prob. Chi-Square(1) & 0.5938 \\
Heteroskedasticity Test: Breusch-Pagan-Godfrey & & 0.0572 \\
F-statistic & 2.460096 & Prob. F(7,24) & 0.0636 \\
Obs*R-squared & 13.36857 & Prob. Chi-Square(7) & \\
\hline
\end{tabular}

Source: Author's Computation, 2020 using Eview 9

\subsubsection{CUSUM Stability Test}

The short-run model is stable as revealed by CUSUM test in the figure 2 below. The CUSUM plot falls within the 5 percent critical bound, which implies that the parameters in the model are stable.

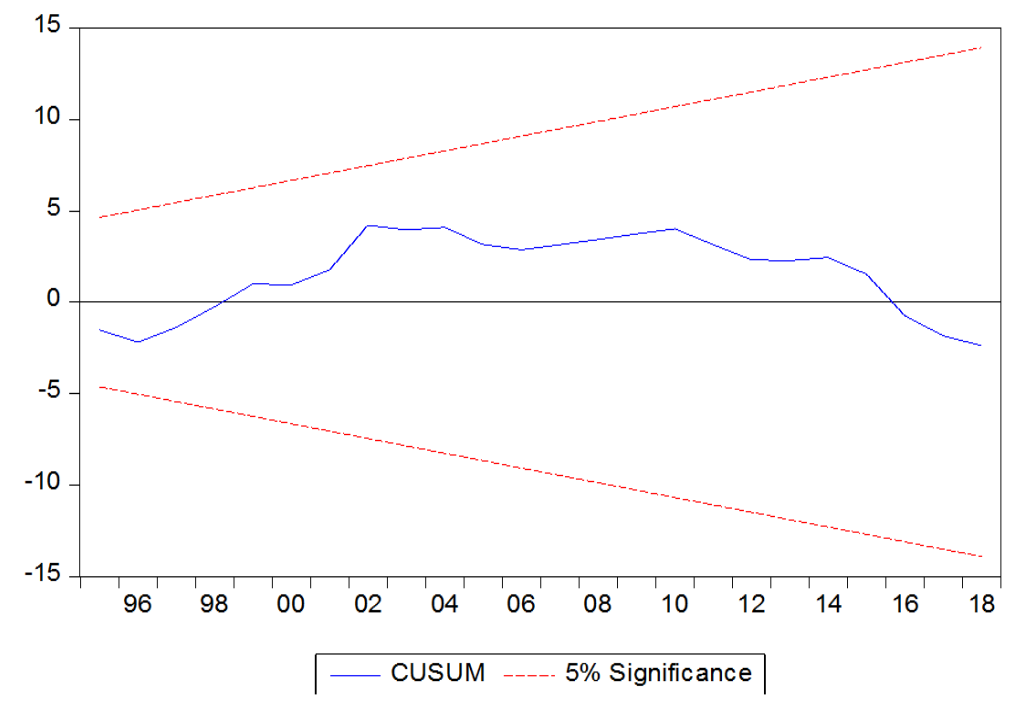

Figure 2. CUSUM Stability Test.

\section{Conclusion and Recommendations}

\subsection{Conclusion}

This study investigates the role of exchange rate on the relationship between foreign direct investment and economic growth in Nigeria over the period 1986 to 2018 . The study concludes that foreign direct investment has positive relationship with economic growth at maximum, average and minimum level of exchange rate but the relationship is only significant at maximum level of exchange rate over the period under study. This means that exchange rate at maximum level positively and significantly affects foreign 
direct investment which pushes and stimulates economic growth. The study also concludes that export has significant positive relationship with economic growth while import showed insignificant negative relationship with economic growth over the period under study.

\subsection{Recommendations}

Based on the results, the following recommendations were made:

i. The depreciation of Nigeria's currency should be encourage so as to allow more inflow of foreign direct investment considering its positive impact on economic growth.

ii. The right and enabling environment should be created in order to attract foreign investors in terms of ensuring security and provision of infrastructure.

iii. The Nigerian government should put in place policies that will encourage Exports and discourage Import. Stringent excise duties should be eliminated while importation that does not lead to economic growth should be discouraged.

\section{References}

[1] Adegboye, C. Ogbebor, O. and Egharyba, I. (2014). External capital flows and economic growth in Nigeria. JORIND, 12 (2), 91-98.

[2] Adeleke, M., Olowe O. and Fasesin O. (2014). Impact of foreign direct investment on Nigeria economic growth. International Journal of Academic Research in Business and Social Sciences. Vol. 4, No. 8. Pp 234-242.

[3] Adeolu A. (2007). FDI and economic growth: evidence from Nigeria. Nairobi: AERC Research Paper 165African Economic Research Consortium. Pp 1-42.

[4] Adigwe, K., Ezeagba, E., and Francis U. (2015). Effect of foreign direct investment on Nigerian economic growth. European Journal of Research and Reflection in Management Sciences. Vol. 3 No. 5, 2015 IS. Pp 28-34.

[5] Alege, O. and Ogundipe A. (2013). Foreign direct investment and economic growth in ECOWAS. a system-GMM approach. Covenant Journal of Business and Social Sciences (CJBSS), Pp 5 (1), 1-22.

[6] Alexander, A., Joshua G. and Tauhid S. (2013). Estimating the impact of foreign direct investment in Nigeria. International Journal of Humanities and Social Science Vol. 3 No. 17. Pp 138-145.

[7] Aminu, Y., U. and Batat, E., H,. N. (2019). Has foreign aid accelerated economic growth? Evidence from Nigeria. Northwest Journal of Social and Management Scineces. Vol. 2 Issue No. 1.

[8] Ansarul, H., Ashok P. and Syeda H. (2017). Foreign direct investment and growth- a study in the context of Kuwait. International Journal of Financial Research. Pp 9-15.

[9] Bakare, A., Tunde A. and Bashorun T. (2014). The two gap model and the Nigerian economy; Bridging the gaps with foreign direct investment. International Journal of Humanities and Social Science Invention Pp 1-14.

[10] Benedict, A. and John C. (2017). Foreign direct investment and economic growth in Nigeria: An empirical analysis. European Journal of Research in Social Sciences. Vol. 5 No. 1. Pp 11-20.

[11] Brambor, T., Clark, R and Golder, M. (2005): Understanding interaction models: improving empirical analyses. Political Analysis, Vol. 14, No. 1 (Winter 2006), pp. 63-82.

[12] Cockcraft L. \& Ridell C. (1991): "Foreign Direct Investment in Sub-Saharan Africa", World Bank Working Papers, No. 61 IMF (1977).

[13] Easterly, P. (2006). The realities of foreign aid to third world countries. London: Keagan Paul.

[14] Edward, M. (2014). Foreign direct investment and Rwanda's economic performance. European Journal of Business and Management. Vol. 6, No. 17, Pp 60-69.

[15] Egwaikhide, I (2012). The impact of foreign direct investment on Nigeria's economic growth: Evidence from the Johansen cointegration approach. International Journal of Business and Social Science. Pp 122-134.

[16] Fredrick, A. and Manasseh O. (2014). The impact of foreign direct investment on economic growth in Nigeria. IOSR Journal of Economics and Finance (IOSR-JEF) Volume 3, Issue 5. PP 37-45.

[17] Goldberg, S. L. (2006). Exchange rates and foreign direct investment. World Investment Report (United Nations).

[18] Ikeanyibe, M. (2009). Development planning in Nigeria: reflections on the national economic empowerment and strategy (NEEDS) 2003-2007. J socsc 20 (3): 197-210.

[19] Jhingan, L. (2012). "The economics of development and planning" ( $40^{\text {th }}$ ed.) Delhi: Vrinda Publications ( $p$ ) Ltd.

[20] Lily, J., Kogid, M., Mulok, D., Sang, T. L., and Asid, R. (2014). Exchange rates movement and foreign direct investment in Asean economies. Economics Research International. Vol. 2014, Article 320949. Pp 1-10.

[21] Murphy, K, Schleifer, A, and Vishny, W. (1989). Industrialization and the Big Push. Journal of Political Economy 97 5, 1003-1026.

[22] National Bureau of statistics (2018). Nigerian capital importation. Retrieved from www.nigerianstat.gov.ng.

[23] National Planning Commission (2005). National economic empowerment and development strategy (NEEDS). (Abridged document).

[24] National Planning Commission (2017). Economic Recovery and Growth Plan (ERGP) Document.

[25] Onyali, I. and Okafor, T. (2014). Foreign direct investment and the Nigerian economy: Vision 2020 mission. Journal of Business and Finance management Research. Pp 8-16.

[26] Pesaran, H, Shin Y. \& Smith, J. (2001): Bound Testing Approaches to the Analysis of Level Relationships. Journal of Applied Econometrics, 16, 289-326.

[27] Organization for Economic Corporation and Development (OECD) (2018). Foreign direct investment statistics. Retrieved from www.oecd.org/investment/statistics.htm. 